\title{
ARMENIAN-AMERICANS IN THE BEHAVIORAL SCIENCES
}

\section{Abstract}

How much are U.S. Armenians involved in psychology and the behavioural sciences? This three-part review details: (1) The origin of the Armenian Behavioral Science Association (ABSA) on 31 August 1987 in New York City. (2) Some highlights of U.S. Armenians involved in the behavioural sciences in general, and psychology in particular. (3) In conclusion, the value of a cross-national census of indigenous Armenian behavioural scientists.

Keywords: Armenians, behavioural science, history

"What are the major contributions of Armenians to the behavioural sciences?" In the worldwide Armenian Diaspora, we have little systematic cross-national information on this question.

In the USA, the Armenian Behavioral Science Association was formed on 31 August 1987 at Fordham University in New York City. This three-part review limns: (1) the origins of ABSA, (2) some highlights of Armenian contributions to psychology and the behavioural sciences in the USA, and (3) a call for a global census of Armenians in psychology and the behavioural sciences.

Origins. ABSA was founded at 6 pm on 31 August 1987, in the elegant rooftop faculty lounge of Fordham University in New York City. This historic, long-in-coming gathering was a "perfect storm" in at least 5 ways: (a) That week the annual meetings of both the American Psychological Association (APA) and International Council of Psychologists (ICP) were in Manhattan, drawing Hye psychologists from many regions. (b) ABSA founders were kindly given program time and space by APA, ICP, and Fordham (Takooshian, 1987a). (c) ABSA had in place 6 Directors representing 6 behavioural sciences: Anny P. Bakalian (sociology/anthropology), Haikaz M. Grigorian (psychiatry), Hagop S. Pambookian (psychology), Mardo Soghomian (political science), Harold Takooshian (social sciences), Richard H. Tashjian (social statistics). (d) After months of planning, the lavish ABSA reception was funded by "tomodon" Haikaz Grirorian's Diaspora Foundation, including piano and patriotic songs with psychologist Shakeh Kaftarian at the piano, and a program featuring over 30 diverse scientists like psychologist Levon Melikian (Beirut), sociologist Levon Chorbajian (Massachusetts), political scientist M. Hratch Zadoian (NYC), Meline 
Karakashian (New Jersey), Harold Goolishian (Texas). (e) The reception was videotaped by A. Vincent Toth (1987), to carry personal greetings to Yerevan colleagues that month by Harold Takooshian, who left that month for a Fulbright Award to Yerevan State University. In turn, in fall of 1987, Takooshian (1987b) videotaped a census of Yerevan psychologists, to share in 1988 with USA colleagues.

From its start, the mission of ABSA is clear: to develop ways to advance the work of Armenians in the behavioural sciences in the USA and globally. One of these is to compile and publish Directories. (a) Right after the massive earthquake on 7 December 1988, ABSA quickly published its first Directory of 304 U.S. Armenian Behavioral Scientists in 1989, flagging 30 who were available for earthquake relief. By 1995, the third ABSA Directory grew to 506 people. Though ABSA no longer publishes a directory, it maintains a growing list of 801 behavioural scientists in the USA and abroad. (b) In addition, ABSA published two other Directories for the Republic of Armenia: 53 sociologists in 15 programs (Poghosian, Kalayjian \& Takooshian, 1991), and 167 psychologists in 38 programs (Vardanyan, Takooshian \& Karakashian, 1991).

Contributions. Behavioural sciences. In the USA, it is striking how each behavioural science has key Armenian-ancestry leaders. This includes: (a) Economics-the legendary Armen Alchian of UCLA, Daron Acemoğlu of MIT. (b) Sociology-the revered Edward A. Tiryakian of Princeton University, Berch Berberoglu of the University of Nevada-Reno, Vahakn N. Dadrian of SUNY-Geneseo. (c) Psychiatry-Hagop Akiskal of the National Institutes of Health, Garabed Aivazian of the University of Tennessee, Allen J. Salerian of DC. (d) Political science-R. Hrair Dekmejian of the University of Southern California, Dennis Papazian and Ronald G. Suny of the University of Michigan. (e) Anthropology-Aram A. Yengoyan of the University of California at Davis. (f) Statistics-Jack Hachigian of Hunter College-CUNY, Richard Haig Tashjian of New York University. (g) Public health-Haroutune K. Armenian of Johns Hopkins University, Myron Allukian of the American Public Health Association.

Contributions. Psychology. Within the U.S. behavioural sciences, Armenians are most concentrated in the field of psychology. While the American Psychological Association recognizes 54 specialty divisions, about half of these specialties have been shaped by an Armenian-ancestry psychologist. This includes APA divisions: 1 GENERAL-Levon H. Melikian; 2 TEACHING-Seth Arsenian; 3 PERSONALITY-Albert Mehrabian; 4 INDUSTRIAL-ORGANIZATIONAL-Arthur G. Bedeian, Charles A. Pounian, Harold $\mathrm{H}$. Kassarjian; 18 PUBLIC SERVICE-Bill Safarjan; 19 MILITARY-Jane Arabian; 20 AGINGJane Mahakian; 26 HISTORY-William G. Sahakian; 36 RELIGION-Raymond F. Paloutzian; 
39 PSYCHOANALYSIS-Hrair M. Babikian; 43 FAMILY-Harold Goolishian; 46 MEDIA-Mary Karapetian Alvord; 47 EXERCISE-John M. Basmajian; 49 GROUP THERAPY-Yvonne Agazarian; 53 CLINICAL CHILD-Susan J. Simonian; 56 TRAUMA-Ani Kalayjian

An ABSA survey completed by 200 of these behavioural scientists found: $49 \%$ are fluent in Armenian, and this fluency significantly correlated with increased involvement in Armenian community activities $(r=+.47, p<.01)$. This survey also found that $66 \%$ were interested in volunteer efforts, $68 \%$ in paid consulting, $61 \%$ in speaking with mass media, $67 \%$ in public speaking, $84 \%$ in counselling students. About half of these are not involved in the U.S. Armenian community, while a small but growing minority of these (about 15\%) are involved in Armenian Studies.

Conclusion. After 30 years, ABSA remains an informal and growing global network of over 800 diverse behavioural scientists and students. who meet at regional conventions. (See Note 1 below.) ABSA continues to offer a platform to unite Hye colleagues and students in the Republic of Armenia and Diaspora nations (Takooshian, 2019). The time has come for to ABSA to cooperate with colleagues in the Republic of Armenia, for a global census of indigenous Armenian behavioural scientist across many nations, to compile a list of scientists in their own nation, and establish a global network.

\section{References}

Poghosian, G., Kalayjian, A., \& Takooshian, H. (Eds.) (1991). Directory of Sociologists in the Republic of Armenia. New York: ABSA.

Takooshian, H. (1987a). Armenian Behavioral Science Association inaugural meeting [A 90-minute DVD]

Takooshian, H. (1987b). A census of psychologists in the Republic of Armenia, 1987. [A 90-minute DVD]

Takooshian, H. (2019). Invited address: The Armenian Behavioral Science Association, 30 years later. Pages 353-355 in $\mathrm{H}$. Avannesyan (Ed.), Proceedings of the conference on 100 years of psychological science at Yerevan State University. https://drive.google.com/file/d/12p3c5ORVSD3uRsnCHTBcq4pAn0QjnMgl/view

Toth, V.A. (1987, August 31). Armenian Behavioral Science Association inaugural reception. [A 90-minute DVD]

Vardanian, G., Takooshian, H., \& Karakashian, M.A. (Eds.). (1991). Directory of Psychologists in the Republic of Armenia. (2 ed.). New York: ABSA. 